\title{
PENINGKATAN KUALITAS DOSEN MELALUI IMPLEMENTASI REGULASI BEBAN TUGAS DOSEN
}

\author{
Oleh : \\ I Gede Dharman Gunawan \\ Dosen Dharma Acarya STAHN-TP Palangkaraya
}

\begin{abstract}
Lecturer is the spearhead and the motor institution of higher education institutions to carry out activities Tridharma. As professionals, lecturers demanded shopped constantly innovative and creative efforts to improve its quality in the field of science which they are. Lecturer is not only a professional educator at the, but also a. The principal tasks of lecturers in the faculty task load regulation covering the fields of, research and community. Besides the main task of the lecturer also has another, namely academic and professional development and participation in higher education. So with the improvement of the quality of lecturers through the implementation of regulatory workload may also increase the welfare of the faculty lecturers.
\end{abstract}

Keywords: Quality Improvement Lecturer, Lecturer Regulatory Burden Task

\section{PENDAHULUAN}

Sebagai paradigma baru, dosen memiliki tugas yang tidak ringan. Sebab, dosen tidak hanya berkewajiban mengajar akan tetapi juga membimbing mahasiswa agar memiliki kompetensi yang relevan dengan keahliannya. Tidak hanya sekedar itu, akan tetapi juga memiliki tanggung jawab pengembangan ilmu pengetahuan melalui penelitian yang semestinya dilakukan secara terus menerus. Bagaimana dosen akan dapat membimbing untuk mahasiswa agar menemukan sesuatu yang baru, jika dosennya sendiri tidak melakukan riset, baik kepustakaan ataupun lapangan. Tanggung jawab dosen yang relatif berat adalah melakukan penelitian secara serius. Di dalam hal ini, maka seorang dosen memanggul tugas untuk menemukan konsep atau teori yang sesuai dengan bidangnya. Sehingga ketika ditanya apakah temuan saudara sebagai dosen di dalam pengembangan ilmu pengetahuan, maka yang bersangkutan bisa menyatakan dengan tegas, ini temuan saya. Dan temuan akademis itulah yang kemudian menjadi kekuatan akademis lembaga atau institusi pendidikan dimana dosen mengabdi di dalam dunia akademik.

UU Nomor 14 tahun 2005 pada pasal 1 menyebutkan Dosen adalah pendidik professional dan ilmuan dengan tugas utama mentranformasikan, mengembangkan, dan menyebarluaskan ilmu pengetahuan, teknologi dan seni melalui pendidikan, penelitian, dan pengabdian kepada Masyarakat. "Dosen tetap adalah dosen yang bekerja penuh waktu yang berstatus sebagai tenaga tetap pada satuan pendidikan tinggi tertentu" (Peraturan Pemerintah Republik Indonesia Nomor 37 tahun 2009 tentang Dosen, pada bab I pasal 1 ayat 2). Profesi sebagai dosen diharapkan memiliki jati diri yang utama dan professional, oleh karena kewajiban dosen yang "professional adalah pekerjaan atau kegiatan yang dilakuakan oleh seseorang dan menjadi sumber penghasilan kehidupan yang 
memerlukan keahlian, kemahiran, atau kecakapan yang memenuhi standar mutu atau norma tertentu serta memerlukan pendidikan profesi" (pasal 1 UU Guru dan Dosen No. 14 tahun 2005).

Dosen tidak hanya dituntut untuk memiliki kualifikasi yang minimal berijazah magister (S2), namun memiliki kompetensi. Kompetensi adalah seperangkat pengetahuan, keterampilan, dan perilaku yang harus dimiliki, dihayati, dan dikuasai oleh guru atau dosen dalam melaksanakan tugas keprofesionalan. Dosen yang memiliki kompetensi professional memiliki fungsi untuk meningkatkan martabat dan peran dosen sebagai agen pembelajaran, pengembang ilmu pengetahuan, teknologi, seni, serta pengabdi kepada masyarakat berfungsi untuk meningkatkan mutu pendidikan nasional. Guna meningkatkan kualitas dosen maka dosen perlu menjunjung tinggi prinsip-prinsip sebagai berikut:a.memiliki bakat, minat, panggilanjiwa, dan idealism; b. memiliki komitmen untuk meningkatkan mutu pendidikan, keimanan, ketakwaan, dan akhlak mulia; c. memiliki kualifikasi akademik dan latar belakang pendidikan sesuai dengan bidang tugas; $d$. memiliki kompetensi yang diperlukan sesuai dengan bidang tugas; e. memiliki tanggung jawab atas pelaksanaan tugas keprofesionalan; f. memperoleh penghasilan yang ditentukan sesuai dengan prestasi kerja; g. memiliki kesempatan untuk mengembangkan keprofesionalan secara berkelanjutan dengan belajar sepanjang hayat; $h$. memiliki jaminan perlindungan hukum dalam melaksanakan tugas keprofesionalam; dan i. memiliki organisasi profesi yang mempunyai kewenangan mengatur hal-hal yang berkaitan dengan tudas keprofesionalan" (pasal 7 UU Guru dan Dosen). Dengan menjalankan semua prinsip sebagaimana dijelaskan di atas, maka dosen mampu meningkatkan kualitas profesionalnya, serta mampu mengimplementasikan semua regulasi tentang beban tugas dosen. Sehingga dosen mampu mengemban tugas yang sangat mulia dan utama untuk mencerdaskan kehidupan Bangsa Indonesia.

\section{PEMBAHASAN}

Peningkatan kualitas dosen dengan pemahaman dan implementasi regulasi yang berkaitan dengan beban tugas dosen dosen pada perguruan tinggi adalah sangat penting sekali, oleh karena dengan pemahaman serta implementasinya tersebut diharapkan tugastugas dosen dapat menjadi tertib, lancar, dan sukses. Keberhasilan kinerja dosen merupakan dasar untuk mencapai keberhasilan untuk mencapai sasaran dan tujuan pendidikan pada perguruan tinggi yakni untuk mencerdaskan kehidupan bangsa Indonesia. Pada bagian ini dipaparkan mengenai beberapa regulasi atau peraturanyang diberlakukan oleh pemerintah untuk selanjutnya dapat diterapkan pada perguruan tinggi. Antara pemahaman dan penerapan aturan yang berlaku di bidang pendidikan tinggi adalah hal utama sebagai acuan bagi para dosen, termasuk juga bagi pengelola pendidikan tinggi di Indonesia.

\subsection{Memahami Regulasi Beban Tugas Dosen}

Upaya untuk memahami keberadaan regulasi di bidang pendidikan tinggi, salah satunya adalah regulasi tentang beban tugas dosen, merupakan upaya positif demi untuk peningkatan kualitas kinerja para dosen pada perguruan tinggi. Sesungguhnya regulasi di bidang pendidikan tinggi telah diberlakukan oleh pemerintah telah diundangkan secara publik, namun upaya pemahaman masih dirasakan adanya keterbatasan terhadap keberadaan regulasi yang terkait. Berkenaan dengan hal tersebut, maka dalam uraian ini mencoba mengetengahkan beberapa regulasi yang berlaku di Indonesia, selanjutnya agar dapat dipahami dan dapat dijadikan acuan penting dalam hal mengimplemantasikannya dalam pelaksanaan tugas rutin oleh para dosen. Mari simak beberapa regulasi terkait dengan beban tugas dosen berikut ini secara sepintas. 


\subsubsection{Regulasi Beban Tugas Dosen Dalam UU} Sisdiknas

Dalam UU Sisdiknas Nomor 20 tahun 2003 pada pasal 19 dan 20 dapat dikutip, yang mengetengahkan tentang pendidikan tinggi. Renungkan bunyi pada 19 dan pasal 20 sebagai berikut: "(1) Pendidikan tinggi merupakan jenjang pendidikan setelah pendidikan menengah yang mencakup program pendidikan diploma, sarjana, megister, spesialis, dan doctor yang diselenggarakan pendidikan tinggi. (2) Pendidikan tinggi diselenggarakan dengan system terbuka”. "(1) Perguruan tinggi dapat berbentuk akademi, politeknik, sekolah tinggi, institut, atau universitas. (2) Perguruan tinggi berkewajiban menyelenggarakan pendidikan, penelitian, dan pengabdian kepada masyarakat. (3) Perguruan tinggi dapat menyelenggarakan program akademik, profesi, dan/atau vokasi. (4) Ketentuan mengenai perguruan tinggi sebagaimana dikasud pada ayat (1), ayat (2), dan ayat (3) diatur lebih lanjut dengan peraturan pemerintah".

\subsubsection{Regulasi Beban Tugas Dosen Dalam UU Guru dan Dosen}

Dalam undang-undang Guru dan Dosen nomor 14 tahun 2005, dalam pasal 51 ada ditegaskan "Dalam melaksanakan tugsa keprofesionalan, dosen berhak: a. memperolah penghasilan di atas kebutuhan hidp minimum dan jaminan kesejahteraan sosial; b. mendapatkan promosi dan penghargaan sesuai dengan tugas dan prestasi kerja; c. memperoleh perlindungan dalam melaksanakan tugas dan hak atas kekayaan intelektual; d. memperoleh kesempatan untuk meningkatkan kompetensi, akses sumber belajar, informasi, srana dan prasarana pembelajaran, serta penelitian dan pengabdian kepada masyarakat; e. memiliki kebebasan akademik, mimbar akademik, dan otonomi keilmuan; f. memiliki kebebasan dalam meberikan penilaian dan menetukan kelulusan peserta didik; dan g. memiliki kebebasan untuk berserikat dalam organisasi profesi/ organisasi profesi keilmuan". Demikian hak dosen begitu jelas dan sangat positif maknanya sebagaimana telah diatur dalam UU Guru dan Dosen, guna dapat dipahami dan diimplementasikan dengan baik dan konsisten oleh para dosen pada jenjang perguruan tingginya masing-masing.

Selanjutnya dalam pasal 60 ditegaskan juga mengenaikewajiban dosen, sebagai berikut: " dalam melaksanakan tugas keprofesionalan, dosen berkewajiban; a. melaksanakan pendidikan, penelitian, dan pengabdian kepada masyarakat; b. merencanakan, melaksanakan proses pembelajaran, serta menilai dan mengevaluasi hasil pembelajaran; c. meningkatkan dan mengembangkan kualifikasi akademik dan kompetensi secara berkelanjutan sejalan dengan perkembangan ilmu pengetahuan, teknologi,dan seni; d. bertindak objektif dan tidak diskriminatif atas dara pertimbangan jenis kelamin, agama, suku, ras, kondisi fisik tertentu, atau latar belakang sosioekonomi peserta didik dalam pembelajaran; e. menjunjung tinggi peraturan perundangan-undangan, hukum, dan kode etik, serta nilai-nilai agama dan etika; dan f. memelihara dan memupuk persatuan dan kesatuan bangsa”.

Pada bagian lainnya dalam yaitu pada pasal 61 ada ditegaskan mengenai wajib kerja dosen yakni “ (1) Dalam keadaan darurat pemerintah dapat memberlakukan ketentuan wajib kerja kepada dosen dan/atau warga Negara Indonesia lain yang memenuhi kualifikasi akademik dan kompetensi untuk melaksanakan tugas sebagai dosen di daerah khusus. (2) Ketentuan lebih lanjut mengenai penugasan warga Negara Indonesia sebagai dosen dalam dalam keadaan darurat sebagaimana dimaksud pada ayat (1) diatur dengan Peraturan Pemerintah". Hal tersebut menegaskan bahwa para dosen memiliki jam kerja sesuai dengan ketentuan yang diberlakukan oleh pemerintah. Intinya bahwa ketentuan jam kerja dosen pengaturannya merupakan kewenangan pemerintah melalui aturan resmi yang 
diberlakukan secara nasional, yang wajib dipatuhi dan ditaati oleh setiap dosen dalam menjalankan tugasnya.

Selanjutnya pada pasal 78 dalam undangundang Guru dan Dosen Nomor 14 tahun 2005, ada ditegaskan mengenai sanksi dosen yakni: "(1) Dosen yang diangkat oleh pemerintah yang tidak menjalankan kewajiban sebagaimana dimaksud dalam pasal 60 dikenai sanksi sesuai dengan peraturan perundangundangan. (2) Sanksi sebagaiman dimaksud pada ayat (1) berupa: a. teguran; b. peringatan tertulis; c. penundaan pemberian hak dosen; d. penurunan pangkat dan jabatan akademik; e. pemberhentian dengan hormat; atau $\mathrm{f}$. pemberhentian dengan tidak hormat". Beberapa sanksi terhadap dosen seperti diuraikan pasal yang telah dikutip di atas, memberikan ingatan kepada para dosen agar jenis sanksi tersebut jangan sampai mengenai para dosen. Namun dalam implementasinya ada dibuktikan adanya pelanggaran aturan yang berlaku, mau tidak mau sanksi tersebut akan mengenai diri para dosen. Maka dari itu perlunya pemahaman dan pelaksanaan tugas dosen dengan sebaikbaiknya penuh disiplin agar tidak dijerat sanksi sesuai peraturan perundang-undangan yang berlaku bagi dosen.

\subsubsection{Regulasi Dalam PP No. 53 tahun 2010 tentang Disiplin PNS}

Dalam pasal 3 pada PPRI Nomor 53 tahun 2010 tentang Disiplin PNS dijelaskan sebagai berikut mengenai kewajiban PNS, bunyinya “ Setiap PNS wajib: 1. Mengucapkan sumpah/ janji PNS; 2. Mengucapkan janji/sumpah jabatan; 3 . Setia dan taat sepenuhnya kepada Pancasila, Undang-Undang Dasar Negara Republik Indonesia Tahun 1945, Negara Kesatuan Republik Indonesia, dan Pemerintah; 4. Menaati segala ketentuan peraturan perundangundangan; 5. Melaksanakan tugas kedinasan yang dipercayakan kepada PNS dengan penuh pengabdian, kesadaran, dan tanggung jawab; 6. Menjunjung tinggi kehormatan Negara, Pemerintah, dan martabat PNS; 7. Mengutamakan kepentingan Negara daripada kepentingan sendiri, seseorang, dan/ atau golongan; 8. Memegang rahasia jabatan yang menurut sifatnya atau menurut perintah harus dirahasiakan; 9. Bekerja dengan jujur, tertib, cermat, dan bersemangat untuk kepentingan Negara; 10. Melaporkan dengan segera kepada atasannya apabila mengetahui ada hal yang dapat membahayakan atau merugikan Negara atau Pemerintah terutama dibidang keamanan, keuangan, dan materiil; 11. Masuk kerja dan menaati ketentuan jam kerja; 12. Mencapai sasaran kerja pegawai yang ditetapkan; 13. Menggunakan dan memelihara barang-barang milik Negara dengan sebaikbaiknya; 14.memberikan pelayanan sebaikbaiknya kepada masyarakat; 15 . Membimbing bawahan dalam melaksanakan tugas; 16. Memberikan kesempatan kepada bawahan untuk mengembangkan karir; 17. Menaati peraturan kedinasan yang ditetapkan oleh pejabat yang berwenang".

Selanjutnya dalam pasal 4 mengenai "Larangan PNS" dijelaskan bahwa "Setiap PNS dilarang: 1. Menyalahgunakan wewenang; 2. Menjadi perantara untuk mendapatkan keuntungan pribadi dan/atau orang lain dengan menggunakan kewenangan orang lain; 3. Tanpa izin pemerintah menjadi pegawai atau bekerja untuk Negara lain dan/atau lembaga atau organisasi interasional; 4. Bekerja pada perusahaan asing, konsultan asing, atau lembaga swadaya masyarakat asing; 5 . Memiliki, menjual, membeli, menggadaikan, menyewakan, atau meminjamkan barangbarang baik bergerak atau tidak bergerak, dokumen atau surat berharga milik Negara secara tidak sah; 6. Melakukan kegiatan bersama dengan atasan, teman sejawat, bawahan, atau orang lain di dalam maupun di luar lingkungan kerjanya dengan tujuan untuk keuntungan pribadi, golongan, atau pihak lain, yang secara langsung atau tidak langsung merugikan Negara; 7. Memberi dan 
menyanggupi akan memberi sesuatu kepada siapapun baik secara langsung atau tidak langsung dan dengan dalih apapun untuk diangkat dalam jabatan; 8. Menerima hadiah atau suatu pemberian apa saja dari siapapun juga yang berhubungan dengan jabatan dan/atau pekerjaannya; 9. Bertindak sewenang-wenang terhadap bawahannya; 10. Melakukan suatu tindakan atau tidak melakukan suatu tindakan yang dapat menghalangi atau mempersulit salah satu pihak yang dilayani sehingga mengakibatkan kerugian bagi yang dilayani; 11 . Menghalangi berjalannya tugas kedinasan; 12. Memberikan dukungan kepada calon presiden/ wakil presiden, Dewan Perwakilan Rakyat, Dewan Perwakilan Daerah, atau Dewan Perwakilan Rakyat Daerah dengan cara: a. ikut serta sebagai pelaksana kampanye; b. menjadi peserta kampanye dengan menggunakan atribut partai atau atribut PNS; c. sebagai peserta kampanye dengan mengerahkan PNS lain; dan/ atau d. sebagai peserta kampanye dengan menggunakan fasilitas Negara; 13. Memberikan dukungan kepada calon Presiden/Wakil presiden dengan cara: a. membuat keputusan dan/atau tindakan yang menguntungkan atau merugikan salah satu pasangan calon selama masa kampanye; dan/atau b. mengadakan kegiatan yang mengarah kepada keberpihakan terhadap pasangan calon yang menjadi peserta pemilu sebelum, selama, dan sesudah masa kampanye meliputi pertemuan, ajakan, himbauan, seruan, atau pemberian barang kepada PNS dalam lingkungan unit kerjanya, anggota keluarga, dan masyarakat; 14. Memberikan dukungan kepada calon anggota Dewan Perwakilan Daerah atau calon Kepala Daerah/Wakil Kepala Daerah dengan cara memberikan surat dukungan disertai foto kopi Kartu Tanda Penduduk atau Surat Keterangan Tanda Penduduk sesuai peraturan perundangundangan; dan 15. Memberikan dukungan kepada calon Kepala Daerah/Wakil Kepala Daerah, dengan cara a. terlibat dalam kampanye untuk mendukung calon Kepala
Daerah/Wakil Kepala Daerah; b. menggunakan fasilitas yang terkait dengan jabatan dalam kegiatan kampanye; c. membuat keputusan dan/atau tindakan yang menguntungkan atau merugikan salah satu pasangan calon selama masa kampanye; dan/ atau d. mengadakan kegiatan yang mengarah kepada keberpihakan terhadap pasangan calon yang menjadi peserta pemilu sebelum, selama, dan sesudah masa kampanye meliputi pertemuan, ajakan, himbauan, seruan, atau pemberian barang kepada PNS dalam lingkungan unit kerjanya, anggota keluarga, dan masyarakat".

\subsubsection{Beban Tugas Dosen Dalam Pedoman} BKD dan Evaluasi Pelaksanaan Tri Dharma Perguruan Tinggi

Dalam Buku Pedoman BKD dan Evaluasi Pelaksanaaan Tri Dharma Perguruan Tinggi Ditjen Dikti Depdiknas Tahun 2010, ada dijelaskan mengenai tugas uatam dosen berupa : a) Tugas melakukan pendidikan merupakan tugas di bidang pendidikan dan pengajaran; $b$ ) Tugas melakukan penelitian merupakan tugas di bidang penelitian dan pengembangan karya ilmiah; c) Tugas melakukan pengabdian kepada masyarakat; dan d) Tugas penunjang tridharma perguruan tinggi.

“a) Tugas melakukan pendidikan merupakan tugas di bidang pendidikan dan pengajaran yang dapat berupa : (1) melaksanakan perkuliahan/tutorial dan menguji serta mnyelenggarakan kegiatan pendidikan di laboratorium, praktik keguruan, praktik bengkel/ studio/kebun percobaan/teknologi pengajaran; (2) membimbing seminar Mahasiswa; (3) membimbing kuliah kerja nyata $(\mathrm{KKN})$, praktik kerja nyata $(\mathrm{PKN})$, praktik kerja lapangan (PKL); (4) membimbing tugas akhir penelitian mahasiswa termasuk membimbing, pembuatan laporan hasil penelitian tugas akhir; (5) penguji pada 
ujian akhir; (6) membina kegiatan mahasiswa di bidang akademik dan kemahasiswaan; (7) mengembangkan program perkuliahan; mengembangkan bahan pengajaran; (9) menyampaikan orasi ilmiah; (10) membina kegiatan mahasiswa di bidang akademik dan kemahasiswaan; (11) membimbing Dosen yang lebih rendah jabatannya; (12) melaksanakan kegiatan datasering dan pencangkokan dosen.

b) Tugas melakukan penelitian merupakan tugas di bidang penelitian dan pengembangan karyailmiah yang dapat berupa: (1) menghasilkan karya penelitian; (2) menerjemahkan/ menyadur buku ilmiah; (3) mengedit/ menyunting karyailmiah;(4) membuat rancangan dan karya teknologi; (5) membuat rancangan karya seni.

c) Tugas melakukan pengabdian kepada masyarakat dapat berupa : (1) menduduki jabatan pimpinan dalam lembaga pemerintahan/pejabat negara sehingga harus dibebaskan dari jabatan organiknya; (2) melaksanakan pengembangan hasil pendidikan dan penelitian yang dapat dimanfaatkan oleh masyarakat; (3) member latihan/ penyuluhan/penataran pada masyarakat; (4) member pelayanan kepada masyarakat atau kegiatan lain yang menunjang pelaksanaan tugas unum pemerintah dan pembangunan; (5) membuat/menulis karya pengabdian kepada masyarakat.

d) Tugas penunjang trudharma perguruan tinggi dapat berupa : (1) menjadi anggota dalam suatu panitia/badan pergururan tinggi; (2) menjadi anggota panitia/badan pada lembaga pemerintah; (3) menjadi anggota organisasi profesi; (4) mewakili perguruan tinggi/lembaga pemerintah duduk di panitia antar lembaga; (5) menjadi anggota delegasi nasional ke pertemuan internasional; (6) berperan aktif dalam pertemuan ilmiah; (7) mendapat tanda jasa/penghargaan; menulis buku pelajaran SLTA kebawah; (9) mempunyai prestasi di bidang olahraga/seni/sosial".

\subsubsection{Regulasi Beban Tugas Dosen Dalam} Peraturan Pemerintah Republik Indonesia Nomor 37 Tahun 2009 Tentang Dosen

Dalam pasal 8, ayat (1), sub b pada Peraturan Pemerintah Republik Indonesia Nomor 37 tahun 2009, tentang disen, ada dinyatakan bahwa dosen "melaksanakan tridharma perguruan tinggi dengan beban kerja paling sedikit sepadan dengan 12 (bua belas) SKS dan paling banyak 16 (enam belas) SKS pada setiap semester sesuai dengan kualifikasi akademiknya dengan ketentuan : 1) beban kerja pendidikan dan penelitian paling sedikit sepadan dengan 9 (Sembilan) SKS yang dilaksanakan di perguruan tinggi yang bersangkutan; dan 2) beban kerja pengabdian kepada masyarakat dapat dilaksanakan melalui kegiatan pengabdian kepada masyarakat yang diselengarakan oleh perguruan tinggi yang bersangkutan atau melalui lembaga lain". Kemudian pada pasal 8, ayat (3), ada dinyatakan mengenai dosen yang diberikan tugas tambahan yakni "Dosen tetap yang mendapat penugasan sebagai pimpinan perguruan tinggi yang bersangkutan sampai dengan tingkat jurusan tetap memperoleh tunjangan profesi sepanjang yang bersangkutan melaksanakan dharma pendidikan paling sedikit sepadan dengan 3 (tiga) SKS di perguruan tinggi yang bersangkutan".

\subsection{Implementasi regulasi beban tugas dosen}

Mengimplementasikan regulasi beban tugas dosen merupakan bagian dari ketentuan yang diberlakukan oleh pemerintah untuk keberlangsungan pelaksanaan pendidikan tinggi yang 
baik, tertib, sukses, dan lancar. Berbagai aktivitas dosen dalam perguruan tinggi memerlukan adanya regulasi yang akurat dan faktual guna terlaksananya proses pembelajarandan pengajaran secara optimal dan terhindarnya berbagai kendala yang muncul. Perguruan tinggi dengan ragarm jenjangnya dan tersebar di berbagai pelosok wilayah binaan pemerintah, baik yang negeri dan swasta, memerlukan adanya pola regulasi yang mampu memberikan petunjuk, tuntunan, serta pedoman bagi pengelola maupun praktisi bidang kependidikan tinggi di Indonesia. Oleh karenanya bahwa begitu pentingnya keberadaan regulasi mengenai beban tugas dosen, yang tidak semata untuk dipahami, namun sangat penting juga untuk dapat diimplementasikan dengan baik dan konsisten, sehingga akan mampu menghasilkan tujuan dan keluaran (out put) yang optimal.

2.2.1 Implementasi regulasi beban tugas dosen tersirat dalam UU Sisdiknas Nomor 20 tahun 2003 yang mengisyaratkan bahwa para dosenyang bertugas pada jenjang pendidikan tinggi, apakah pada akademi, politeknik, sekolah tinggi, institut maupun pada university, merupakan tempat para dosen untuk melaksanakan tugas kedosenan, yang diharapkan mampu untuk menerapkan regulasi tersebut secara efektif dan efisien. Pada jenjang pendidikan tinggi manapun dosen melaksanakan tugasnya, diharpakan dapat mencetak dan menamatkan peserta didik yang memiliki kualitas didikan yang terampil, berprestasi, dan bertanggungjawab.

2.2.2 Implementasi UU Guru dan Dosen Nomor 14 tahun 2005 dinyatakan agar dosen wajib melaksanakan tugas secara profesional. Tugas profesional dosen dalam undang-undang tersebut yakni "dalam melaksanakan tugas keprofesionalan, dosen berkewajiban : a. melaksanakan pendidikan, penelitian, dan pengabdian kepada masyarakat; b. merencanakan, melaksanakan proses pembelajaran, serta menilai dan mengevaluasi hasil pembela-jaran; c. meningkatkan dan mengembang-kan kualifikasi akademik dan kompetensi secara berkelanjutansejalan dengan perkembangan ilmu pengetahuan, teknologi,dan seni; d. bertindak objektif dan tidak diskriminatif atas dara pertimbangan jenis kelamin, agama, suku, ras, kondisi fisik tertentu, atau latar belakang sosioekonomi peserta didik dalam pembelajaran; e. menjunjung tinggi peraturan perundangan-undangan, hukum, dan kode etik, serta nilai-nilai agama dan etika; dan f. memelihara dan memupuk persatuan dan kesatuan bangsa". Bila semua tugas mulia dan suci tersebut sesuai ketentuan dalam undang-undang guru dan dosen diimplementasikan dengan baik dan konsisten, maka semua dosen akan menjadi dosen yang berkualitas, memiliki loyalitas, memiliki integritas, dan bertanggung jawab dengan tugas atau kewajibannya yang utama dan luhur tersebut. Dosen yang demikian patut ditiru dan digugu dalam pendidikan tinggi ke depan.

2.2.3 Implementasi regulasi PPRI Nomor 53 tahun 2010 tentang Disiplin PNS, hal ini penting dipahami, dimengerti, dicamkan dengan seksama. Namun demikian tidak cukup hanya untuk dipahami saja, yang lebih penting adalah mentaati regulasi disiplin PNS yang sekaligus juga menyangkut disiplin dosen, mengingat dosen berstatus sebagai PNS, terkecuali doden yang non PNS. Pada jenjang 
pendidikan tinggi yang negeri dibinaoleh pemerintah, yang pastinya diimplemen-tasikan PP 53/2010 mengenai disiplin PNS. Hal tersebut diperhatikan dan dilaksa-nakan dengan baik dan tertib. Lebih-lebih ada pasal 3 tentang kewajiban PNS yang banyak 17 point dan pasal 4 mengenai larangan PNS yang banyak ada 15 point. Dalam kaitan dengan kewajiban sebagai PNS maka pada pasal 3 angka 11 ada menegaskan kewajiban PNS yakni " masuk kerja dan menaati ketentuan jam kerja". Selain itu juga diwajibkan bekerja dengan jujur, penuh semangat, tertib, dan menjaga hal-hal tergolong rahasia jabatan, juga wajib melaporkan halhal yang membahayakan dalam pelaksanaan tugas. Intinya semua kewajiban agar dipatuhi serta semua larangan jangan sampai dilanggar, oleh karena ada sanksi yang tegas terhadap implementasi regulasi mengenai disiplin PNS tersebut.

2.2.4 Implementasi pedoman BKD dan Evaluasi Pelaksanaan Tri Dharma Perguruan Tinggi yang dikeluarkan oleh Ditjen Dikti Depdikbud RI, dengan jelas sangat akurat dan faktual untuk diimplementasikan dengan konsisten bagi dosen. Jika pedoman ini terabaikan, maka berarti dosen itu tidak paham dengan tugas-tugasnya. Bisa jadi dosen itu hanya statusnya saja sebagai dosen,namun kalang kabut dalam melaksanakan tugas dirinya sebagai dosen. Dalam pedoman tersebut yang telah diatur oleh instansi berkompeten tersebut wajib diimplemen-tasikan dengan komitmen yang baik dan konsisten. Tugas utama dosen adalah melaksanakan tri dharma perguruan tinggi yakni melaksanakan pendidikan dan pengajaran, melaksanakan pemelitian dan pengembangan ilmu, serta melaksanakan pengabdian kepada masyarakat. Selanjut-nya tugas penunjang juga jangan sampai terabaikan dalam tugas penting sebagai dosen.

2.2.5 Implementasi mengenai Peraturan Pemerintah Republik Indonesia Nomor 37 tahun 2009 tentang Dosen merupakan ketentuan penting dipahami dan diimplemetasikan bagi dosen, mengingat tugas dosen jangan sampai melebihi target atau over load dalam tugasnya. Hal tersebut memberikan ingatan kepada setiap dosen, agar tidak memaksakan dirinya untuk mengampu mata kuliah melebihi tugas sebenarnya yang diamanatkan dalam regulasi tentang dosen. Paling sedikit mengampu 12 SKS dan paling banyak 16 SKS dalamsatu semester. Dalam hitungan waktu 12 SKS sepadan dengan 36 jam dalam seminggu. Begitu pula jika mengampu paling banyak 16 SKS berarti dosen sudah bertugas seminggu melebihi waktu yakni 48 jam, karena dalam 1 SKS disamakan dengan 50 menit. Begitu juga jika dosen yang diberikan tugas sebagai dosen dan tugas tambahan menjadi pimpinan, maka beban tugas dosenya hanya 3 SKS saja. Hal ini dimaksudkan, agar dosen yang diberikan tugas tambahan bisa dijalankan tugasnya dengan optimal. Oleh karena tugas tambahan merupakan tugas kepercayaan yang diberikan kepada dosen yang bersangkutan. 


\section{KESIMPULAN}

Peningkatan kualitas dosen dengan mengimplementasikan regulasi beban tugas dosen pada jenjang pendidikan tinggi sangatlah penting bagi dosen maupun pengelola pendidikan tinggi. Terdapat banyak hal yang menyangkut tugas dosen yang telah diatur oleh Pemerintah melalui regulasi resmi yang telah diundangkan secara nasional. Menjadi perhatian penting bagi para dosen agar regulasi yang berlaku dapat dipahami dengan baik dan diimplementasikan dengan konsisten dan dengan penuh komitmen. Profesi dosen sesungguhnya merupakan jabatan yang sangat mulia dan banyak diminati oleh WNI yang telah memenuhi persyaratan. Jangan sampai jabatan dosen disalahgunakan dan dilanggar semuanya tanpa mengindahkan regulasi yang berlaku. Semoga melalui pemahaman dan implementasi regulasi tugas dosen dapat menghasilkan dosen yang disiplin, berprestasi, dan bertanggungjawab. Pada akhirnya dapat menciptakan atau menghasilkan output dosen yang berkualitas dan berguna bagi pendidikan dan kemajuan bangsa Indonesia kedepannya.

\section{DAFTAR PUSTAKA}

Undang-Undang Nomor 20 Taahun 2003 tentang Sistem Pendidikan Nasional

Undang-Undang Nomor 14 tahun 2005 tentang Guru dan Dosen

Peraturan Pemerintah Republik Indonesia Nomor 37 tahun 2009 tentang Dosen

Peraturan Pemerintah Republik Indonesia Nomor 41 tahun 2009 tentang Tunjangan Profesi Guru dan Dosen, Tunjangan Khusus Guru dan Dosen, serta Tunjangan Kehormatan Profesor

Peraturan Pemerintah Republik Indonesia Nomor 53 tahun 2010 tentang Disiplin PNS

Keputusan Dirjen Dikti Depdikbud Republik Indonesia No. 48/D3/Kep/1983 Tentang Beban Tugas Tenaga Pengajar Pada Perguruan Tinggi

Pedoman BKD dan Evaluasi Pelaksanaaan Tri Dharma Perguruan Tinggi Ditjen Dikti Depdiknas Tahun 2010 